\title{
The effects of ownership structure on corporate value in the Tehran Stock Exchange (TSE)
}

\author{
Sohrab Osta ${ }^{\mathbf{a}}$ and Hossein Naderi ${ }^{\mathbf{b}^{*}}$
}

${ }^{a}$ Ilam University, Department of Accounting

${ }^{b}$ Islamic Azad University(IAU)- Ilam Branch, Department of Accounting

ART I CLEINF O ABSTRACT

Article history:

Received October 1, 2011

Received in Revised form

November, 14, 2011

Accepted 30 January 2012

Available online

17 February 2012

Keywords:

Ownership Structure

Ownership concentration

Institutional Ownership

Corporate value

\begin{abstract}
In the present study, the separate and simultaneous role of concentration and type of ownership on corporate value is investigated. In this study, the ownership structure is classified into four classes: the institutional ownership, the corporate ownership, the management ownership and the foreign ownership. In addition, different attitudes regarding the above ownership are also tested, that is, active monitoring hypothesis and interest convergence hypothesis. Since, in the sample research no information was found about foreign ownership, this type of ownership was not examined. However, in the case of the other ownerships, a separated hypothesis was developed based on various techniques and their influence on the corporate value was examined. For each hypothesis, a multiple linear regression model is defined based on the dependent variables. Companies listed in securities exchange commission of Iran makes up the statistical community of present study and the sample consists of 90 companies during 20022008. Two types of tests, including correlation test and cross multiple regression test are implemented to examine the hypothesis. Generally, the results reflect no significant relationship between the concentration of ownership and the corporate value. The results of the study show that, while there is no relationship between the institutional ownership and management ownership and the corporate value, there is a significant relationship between the corporate ownership and the corporate value.
\end{abstract}

\section{Introduction}

Corporate governance (CG) has been considered as one of the most interesting subjects in agency theory. CG deals on how to cope with an existing conflict of interest among various groups in a particular firm. According to Jensen \& Meckling (1976), the agency relationship is a communication between one or more shareholder and owners where the agent is responsible for some services. In the agency theory, the owner's goal is wealth maximization and to achieve this objective, they monitor the agent's work and evaluate his/her performance. Determining the type of the ownership structure is a control tool in corporate and it involves with the type of the corporate ownership such as the ownership distribution, the concentration of ownership, the minority and majority shareholders in the texture of the corporate ownership.

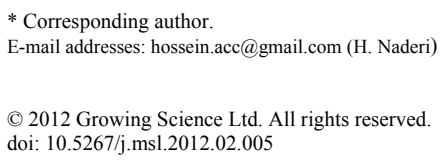


The ownership structure may lead to changes in the corporate behavior. This is due to the monitoring activities that the various investors are doing in this structure (Velury \& Jenkins, 2006). In this case, the question is whether the corporate value and the return are influenced by various structure of the corporate ownership or not. Velury and Jenkins (2006) conducted on the surrounding ownership type, the role of different types of ownership including state ownership, institutional ownership, corporate ownership, individual and family ownership, foreign ownership, management ownership and other types of ownership on the value of corporate and their returns.

The main goal of present study is to evaluate the impact of ownership structure on corporate value in the Tehran Stock Exchange (TSE). Importance of this research is that it shows experimentally managers, investors and other decision makers that being different corporate ownership structure influences on corporate value. Namely, value of corporate will be different when the company's owners are among various groups like government, financial institutions, banks, private companies and other ownership.

In addition, we also determine the most effective items for promoting corporate value. In addition, according to constitutional article 44 in Iran, the state tries to privatize governmental companies. On the other hand, private ownership includes corporate ownership, management ownership and foreign ownership and among them, two sets have been evaluated and their effects on the company value in the present paper to expose benefits of privatization namely: corporate ownership and management ownership are discussed.

\section{Literature and review of previous researches}

In most studies on corporate values, the role of ownership structure was poorly exposed and various aspects of the property have not been considered. Four types of ownerships including, the institutional ownership, corporate ownership, managerial ownership and foreign ownership have been evaluated in the present study. According to Bushee (1998), institutional investors are big investors such as banks, insurance companies, investment companies, etc., where their presence in companies led to changes in corporate behavior.

In addition, corporate investors include non-governmental entities and management investors are family companies being major ownership of companies in this study. However, foreign ownership has not been found due to lack of foreign companies. In this study, we have studied different perspectives on these structures. One of these hypotheses is the active monitoring hypothesis. When the manager controls most parts of the company's shares may expose behavior in contrast with the goal of maximizing corporate value. Another hypothesis is the convergence of interests, when the manager, is the owner of low percentage of the company's shares usually precede under the influence of market forces and effective supervision to maximize the value of the institute. Combining these two hypothesis lead to a non-linear relationship between ownership and corporate value ratio shown in Appendix-II chart.

Jensen and Mecking (1976) conducted much research on distribution of ownership and its impact on corporate value and predicted that the corporate value is a function of how the company allocates shares between internal and external individuals of company. They stated that more stock ownership by the board is improved corporate value. Shahira (2003) showed in his study in Egypt that there was no meaningful relationship between ownership type and P / BV and P / E indicators, but they found a meaningful one between the type of ownership and ROA and ROE indicators. Kumar (2004) considered the effect of type of ownership structure on corporate value and through studying in India he determined that managers had the greatest impact on corporate performance whereas foreign shareholders were not efficient in corporate performance. 
Chapelle (2004) showed that some active companies in Belgium had concentrated ownership structure in Belgium stock market, because the concentration of ownership is one of the ways of controlling on corporations. Kim et al. (2006) indicated that companies having efficient governing system had better performance in his survey by investigating some Korean firms. Shleifer and Vishny (1986) determined that the present institutional investors had the positive impact on company value because of increasing efficient supervision.

Morck et al. (1998) decided that there would not be any relationship between management ownership and institution's market value of assets whereas this relationship existed according to hypothesis of interest convergence. Barberies et al. (1996) concluded that any changes in ownership structure led to maximizing company values by considering performance changes in 452 Russian companies. Earle (1998) and Kocenda and Svejnar (2002), reported similar conclusions based on positive impact on private ownership rather than state one in separate studies respectively in countries Russia and Czech Republic by studying the effects of ownership framework on companies performance.

Bushee (1998) studied much on this field and stated that institutional investors as a type of corporate ownership structure led to changing companies behavior. He also added that the institutional investors controlled enterprises explicitly through collecting information and through managing corporation performance. Deb and Chaturvedula (2003) investigated the relationship between ownership structure and value in Indian firms by testing for "Monitoring and Expropriation" hypothesis as well as "Convergence of Interest" and "Entrenchment hypothesis". They provided evidences in support of monitoring hypothesis but they could not find any evidence in support of expropriation hypothesis. They reported evidence in support of both "convergence of interest" and "entrenchment hypothesis". de Miguel et al. (2003) reported different findings, which are as follows.

First, different factors such as investor protection, development of capital markets, activity of the market for corporate control, and effectiveness of boards influence ownership concentration and insider ownership levels. Second, the relationship between ownership concentration and firm value is not directly affected by these institutional factors. Third, There is, however, a direct influence of corporate governance characteristics on the relationship between insider ownership and firm value.

There is an evidence, which indicates that corporate ownership structure plays an important role in determining the incentives of insiders to expropriate minority shareholders during times of declining investment opportunities. Their results add to the literature that examines the link between ownership structure and firm performance and provide additional guidance to policy makers engaged in the ongoing debate about the proper role and design of corporate governance features and legal institutions in developing economies (de Miguel et al., 2003; Lins, \& Lemmon, 2001).

\section{Hypothesis and research goals}

The current paper is to examine the effect of ownership framework on enterprise value, its ratio and number of present owners on structure of company's capital. Ownership structure is divided in to including:

1. Institutional Ownership,

2. Corporate Ownership,

3. Management Ownership,

4. Foreign ownership. 
However, since related information was not found in the mentioned sample study, no hypothesis has been developed for this kind of ownership. So hypotheses of the research include:

Hypothesis 1: There is a meaningful relationship between the level of institutional owners and corporate value.

Hypothesis 2: There is a meaningful relationship between the degree of concentration of institutional owners and corporate value.

Hypothesis 3: There is a meaningful relationship between the level of corporate owners and corporate value.

Hypothesis 4: There is a meaningful relationship degree of concentration of corporate owners and corporate value.

Hypothesis 5: There is a meaningful relationship between the level of management owners and corporate.

Hypothesis 6: There is a meaningful relationship degree of concentration of management owners and corporate value.

\section{Data and Methodology}

Statistical population of the current paper includes companies listed in security exchange commission in Iran with the following needed qualifications:

1. Their financial year-end should be on March 29 and they should be active in exchange from 2001 until 2008.

2. Financial information required, especially notes attached to financial statement.

3. Fiscal years of companies should not any changed during the period of study.

According to the above mentioned conditions, 90 companies from 2001 to 2008 were selected as samples. In this study, data related to 90 samples was extracted from sources including RAHAVARIN, stock sites, TADBIRPARDAZ software, etc. Then, statistical tests were conducted using Excel and Spss software packages. This research has applied methods of consolidated data in order to study the effect of ownership concentration and type on value of corporate. The present study is a descriptive one applied in lights of target and goals. There has been introduced a relationship between variables and also a meaningful relationship for variables depended on analyzing regression. For this reason, some models have been introduced for each one of the hypothesis of the study as following:

Model 1. This model has been designed for hypotheses 1 and 2 (institutional owners).

$\mathrm{Val}=\alpha+\beta_{1} \mathrm{INOWN}+\beta_{2} \mathrm{INCONC}+\beta_{3} \mathrm{~PB}+\beta_{4} \mathrm{SIZE}+\beta_{5} \mathrm{DEBT}+\beta_{6} \mathrm{LOSS}+\beta_{7} \mathrm{CROWTH}+\varepsilon_{\mathrm{it}}$.

Model 2. This model has been designed for hypotheses 3 and 4 (corporate owners).

$\mathrm{Val}=\alpha+\beta_{1} \mathrm{COROWN}+\beta_{2} \mathrm{ICORCONC}+\beta_{3} \mathrm{~PB}+\beta_{4} \mathrm{SIZE}+\beta_{5} \mathrm{DEBT}+\beta_{6} \mathrm{LOSS}+\beta_{7} \mathrm{CROWTH}+\varepsilon_{\mathrm{it}}$. 
Model 3. This model has been designed for hypotheses 5 and 6 (management owners).

$\mathrm{Val}=\alpha+\beta_{1} \mathrm{MGROWN}+\beta_{2} \mathrm{MGRCONC}+\beta_{3} \mathrm{~PB}+\beta_{4} \mathrm{SIZE}+\beta_{5} \mathrm{DEBT}+\beta_{6} \mathrm{LOSS}+\beta_{7} \mathrm{CROWTH}+\varepsilon_{\mathrm{it}}$.

where

Val $=$ Value of Company

INOWN $=$ ratio of institutional ownership

INCONC $=$ degree of institutional ownership concentration

COROWN $=$ ratio of corporate ownership

CORCONC $=$ degree of corporate ownership concentration

MGROWN $=$ ratio of management ownership

MGRCONC $=$ degree of management ownership concentration

$\mathrm{PB}=$ growth index (computed by the ratio of market value of equity to its book value)

SIZE $=$ size of firm (normal logarithm of total assets of the company $i$ during the sample period)

DEBT $=$ leverage (calculated via the ratio of long-term debt to total assets.)

Loss $=$ artificial variables (if the company has losses, 1 otherwise 0 )

CROWTH $=$ percentage change in total assets of the company $i$ at the end year $t$ toyeart- 1

$\varepsilon_{i t}=$ unknown component

$\mathrm{CONC}=$ concentration of ownership that is changing is simply how to distribute the shares among share holders is greater than the number of shareholders will be focused acquisitions.

In the present study to calculate the concentration ratio of ownership of the Herfindahl-Hirschman index is used. This index is an economic indicator and is obtained through the percentage squared total of shares owned by corporate share holders and for each type of ownership is calculated as follows:

Degree of institutional ownership concentration $=\sum_{i=1}^{n} I N O W N^{2}$

Degree of corporate ownership concentration $=\sum_{i=1}^{n} C O R O W N^{2}$

Degree of management ownership concentration $=\sum_{i=1}^{n} M G R O W N^{2}$ 
The resulting index is between 0 and 1 , if the result is a near to 1 , represents concentration and the other hand, if is close to zero, would indicate lack of concentration.

\section{Research findings}

In Table 1, descriptive statistics about the test variables is given. Statistical indicators in this table, the number of observations, mean and standard deviation are shown.

\section{Table 1}

Summary Statistics of all the variables (Number of observations $=630$ )

\begin{tabular}{cccccccc}
\hline Statistical proxy & PB & SIZE & DEBT & CROWTH & INOWN & COROWN & CONC \\
\hline Mean & 0.31 & 26.91 & 0.71 & 0.27 & 0.69 & 0.33 & 0.25 \\
Std.Dev. & 0.27 & 1.6 & 0.15 & 0.29 & 0.31 & 0.27 & 0.26 \\
\hline
\end{tabular}

In Table 2 , the results of hypotheses testing 1 and 2 are given in the form of model 1 designed.

\section{Table 2}

Estimated parameters Hypothesis 1, 2(Model 1., Adjusted F 12.55)

\begin{tabular}{ccccccccc}
\hline Statistical proxy & PB & SIZE & DEBT & LOSS & CROWTH & INOWN & INCONC \\
\hline Coefficients & 2.45 & 0.29 & -3.25 & 0.1 & 4.33 & -4.33 & -0.47 \\
P-Value & 0.019 & 0.049 & 0.03 & 0.11 & 0.015 & 0.021 & 0.0971 \\
\hline
\end{tabular}

According to Table 2, among the control variables, variables PB, SIZE, DEBT, and CROWTH in $95 \%$ significance level are significant. On the other hand, F statistics indicated significant overall regression model was fitted to the confidence level is $95 \%$. According to the results of the variable coefficient INOWN (institutional ownership ratio) is obtained negative indicating a negative correlation between the ratio of institutional ownership and corporate value, but because the $95 \%$ level of significance is indicated first hypothesis is confirmed.

Also according to the results of Table 2 Variable Coefficient INCONC (degree of institutional ownership concentration) obtained a negative, but because the level of $95 \%$ is not significant, indicating the second hypothesis is rejected, i.e. between institutional ownership concentration and corporate value significant relationship does not exist.

In Table 3, the results of hypotheses testing 3 and 4, is given in the form of 2 models designed. According to Table 2, among the control variables, variables PB, SIZE, DEBT, and CROWTH in $95 \%$ significance level are significant. On the other hand, F statistics indicated significant overall regression model was fitted to the confidence level is $95 \%$.

Table 3

Estimated parameters Hypothesis 3, 4 (Model 2., Adjusted F 7.46)

\begin{tabular}{cccccccc}
\hline Statistical proxy & PB & SIZE & DEBT & LOSS & CROWTH & COROWN & CORCONC \\
\hline Coefficients & 1.51 & 0.18 & -1.75 & 0.11 & 3.45 & 4.97 & 0.25 \\
P-Value & 0.01 & 0.035 & 0.02 & 0.052 & 0.025 & 0.01 & 0.67 \\
\hline
\end{tabular}

According to the results of Table 3, the variable coefficient of corporate ownership (COROWN) obtained positive, which shows a direct correlation between corporate ownership ratio and corporate value and also because the level of significance is $95 \%$ represents the third hypothesis is confirmed. According to Table 3 and the coefficient of variable degree of corporate ownership concentration (CORCONC), because in the level of $95 \%$ is not significant, so the fourth hypothesis is rejected, which means there is no significant relationship between degree of corporate ownership concentration and corporate value. 
Table 4

Estimated parameters Hypothesis 5, 6 (Model 2., Adjusted F 7.46)

\begin{tabular}{cccccccc}
\hline Statistical proxy & PB & SIZE & DEBT & LOSS & CROWTH & MGROWN & MGRCONC \\
\hline Coefficients & 2.35 & 0.19 & -2.75 & 0.2 & 2.77 & -3.9 & -0.15 \\
P-Value & 0.01 & 0.02 & 0.02 & 0.011 & 0.012 & 0.03 & 0.87 \\
\hline
\end{tabular}

In Table 4, the results of hypotheses testing 5 and 6 , is given in the form of 3 models designed. According to Table 4 of the control variables, variables PB, SIZE, DEBT, CROWTH 95\% significance level are significant. On the other hand, F statistics indicated significant overall regression model was fitted to the confidence level is $95 \%$. According to the results of the variable coefficient MGROWN (management ownership ratio) is obtained negative reflecting the inverse relationship between management ownership ratio and corporate value, but because the $95 \%$ level is significant indicating the fifth hypothesis is confirmed. Also according to the results of the variable coefficient MGRCONC (Degree of management ownership concentration) because the 95\% level of significance has been the sixth hypothesis is rejected, it means there is no significant relationship between management ownership concentration and corporate value.

\section{Conclusion}

Based on findings one can conclude that any change in the type of ownership structure leads to changes in behavior of the companies. (This confirms the result of the survey named Velury and Jenkins having conducted in 2006). However, this type of behavior change is effective on the company value regarding ownership type. The resent paper introduces corporate ownership the best one as a type of this framework, in other words, dominating this ownership on the company causes improving the status of enterprise and finally its value. Because this type of ownership seeks to follow better performance and increased profits for the companies. However, the other types of ownership, namely institutional ownership and management ownership are inversely correlation to corporate value. In the other word, the purpose of this type of ownership is getting less gain and profit, so their presence in the structure of corporate ownership can make their performance weaker. By the way, since no information on foreign owners in corporate ownership structure, this type of property did not review. In addition to the mentioned cases on ownership concentration, no meaningful relationship found between corporate value and ownership concentration where it indicated itself refusing the hypothesis of convergence interest.

\section{References}

Barberies, N. Boyocho, M. shleifer, A., \& Tsukanova, N. (1996). How does privatization work? Evidence from Russian shops. Journal of Political Economy, 104(4), 764-790.

Bushee, B.J. (1998). The Influence of Institutional Investors on Myopic R\&D Investment Behavior. Accounting Review, 73, 305-333.

Chapelle, A. (2004). Block investments and the race for corporate control in Belgium. Center Emile Bernheim, Research Institute in Management Sciences.

de Miguel, A., Pindado, J., \& de la Torre, C. (2003). How Does Ownership Structure Affect Firm Value? A Comparison Using Different Corporate Governance Systems. Social Science Research Network.

Deb, S. S., \& Chaturvedula, C. V. (2003). Ownership Structure and Firm Value: Empirical Study on Corporate Governance System of Indian Firms.

Earle, J.S. (1998). Post-Privatization Ownership Structure and Productivity in Russian Industrial Enterprises. Site Working paper, No127. Stockholm School of Economics.

Kim, W., Black, B.S., \& Jang, H. (2006). Does corporate governance predict firms' market values? Evidence from Korea. Journal of Law, Economics, and Organization, 22(2), 660-691. 
Kocenda, E, \& Svejnar, J. (2002). The Effects of Ownership From and Concentration on Firm Performance after Large-scale Privatization. William Davidson Institute Working paper. N471

Kumar, J. (2004). Does Ownership Structure Influence Firm Value?: Evidence from India. India Gandhi Institute of Development Researches India.

Lins, K. V., \& Lemmon, M. L. (2001). Ownership structure, corporate governance, and firm value: Evidence from the East Asian financial crisis. William Davidson Institute Working Paper No. 393; 3rd Annual Financial Marketing Development Conference, Hong Kong.

Jensen, M.C. (1993). The modern industrial revolution, exit and the failure of internal control systems. Journal of Finance, 48, 830-870.

Jensen, M. C., \& Meckling, W. H. (1976). Theory of the firm: Managerial behavior, agency costs and ownership structure. Journal of Financial Economics, 3, 305-360.

Morck, R., Shleifer, A., \& Vishny, R. (1998). Management Ownership and Market valuation. Journal of Financial Economics, 20, 290-300.

Shahira, A. S. (2003). Does Ownership Structure affect Firm value: Evidence from the Egyptian Stock Market. Cario \& Alexandria Stock Exchanges.

Shleifer, A., \& Vishny, R. (1986). Large shareholders and corporate control. Journal of political Economy, 94, 460-480.

Velury, U., \& Jenkins, D.S. (2006). Institutional Ownership and the Quality of Earnings. Journal of Business Research, 59, 1043-1051. 